\title{
MODALITY AND ASPECT: INTERACTION OF CONSTRUCTIONAL MEANING AND ASPECTUAL MEANING IN THE DATIVE-INFINITIVE CONSTRUCTION IN RUSSIAN
}

\section{INTRODUCTION}

In the literature on modality there has been an increasing interest for the interaction and relation between aspect and modality in Slavic (for example Paducheva 2006; Rappaport 1985; Trnavac 2006; Wiemer 2001). Most of these studies proceed from cross-linguistically defined notions of modality, or even more abstract cross-linguistic notions (e. g. Trnavac 2006, who deals with the notion of subjectivity), and try to determine whether a correlation can be established between these modal notions, and the aspectual use of a form or construction. In many of these analyses, the dative infinitive construction in Russian (henceforth DI) plays an important part, primarily because the aspect of the infinitive is an important factor in the specific modality type associated with this construction. The general pattern observed in the literature on the DI is that (im)possibility is correlated with the perfective aspect, whereas the imperfective aspect is typical of necessity (see Bricyn 1990; Fortuin 2000; Maurice 1995, 1996 and Timofeev 1950). The correlation between epistemic modality and aspect seems a matter of some debate. Some argue that it is correlated with the perfective aspect (e. g. Wiemer 2001, 201), in line with the general association between epistemic modality and the perfective aspect in Russian (Wiemer 2001, 217), whereas others see a relation with the imperfective aspect (e. g. Fortuin 2000).

Analyses of the aspectual usage of specific forms such as the DI which proceed from cross-linguistically modality types can provide a deeper understanding of the relation between aspect and modality cross-linguistically (see Van der Auwera and Plungian 1998 for a state of the art overview of such modality types). It is, however, important to accompany such studies with analyses that focus on the specific semantics of forms, and the internal logic of aspect of these forms. In this paper, I will provide such an analysis.

As I will show, the aspectual usage of the DI differs considerably from other modal forms. This is foremost due to the fact that the modality of the DI is syntactically derived, and not expressed by one specific form. This is not to say though, that the aspectual use of the DI is an idiosyncratic phenomenon of the DI. Similar aspectual patterns can be found with other syntactic expressions of modality, and other non-modal constructions. This means that the aspectual 
usage of the DI can be explained by the interaction of the semantics of the DI and the semantics of Russian aspect. The general conclusion of this paper is that in dealing with semantic phenomena of a particular form in a particular language, a description of the data in terms of general and abstract linguistic notions is not enough, and that one also needs to refer to the specific semantics and syntax associated with forms in language.

\section{MEANING OF THE DI AND MEANING OF ASPECT}

The approach that I will take in this paper is to look at the interaction of the meaning of the DI, and the meaning of aspect in Russian. In this section, I will briefly discuss these meanings.

The minimal elements of the DI are a perfective or imperfective infinitive, and a noun or pronoun in the dative. In some cases the DI occurs with a past tense, or future tense form of быmь ('be') with impersonal (third person singular neuter) marking (было, будет), but such cases are very infrequent. The general or abstract meaning of the DI is that the participant expressed by the dative is the recipient of the situation expressed by the infinitive. This means that there is a force directed at the realization of the infinitive situation by the participant expressed in the dative (see Fortuin 2000, for a more thorough analysis, and an analysis of the relation between the meanings of the constituents and the general meaning). ${ }^{1}$ In sentences without the particle $6 b l$, the main interpretations of the DI are necessity or impossibility. The difference between the necessitive interpretation and the impossibility interpretation relates to the question of whether the intention or tendency of the subject to create the situation is taken into consideration. See figure 1 for a graphic representation.

As I will show in the following sections, the main linguistic factor that distinguishes these interpretations is the aspect of the infinitive.

(Negation of) necessity: imposing

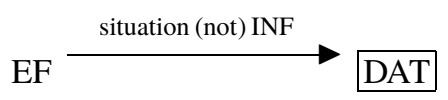

(Negation of) possibility: blocking (or deblocking)

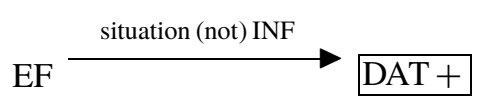

DAT $=$ dative-participant (' + ' points at the intention of the potential agent to fulfill the situation); $\mathrm{EF}=$ contextually given external force; $\mathrm{INF}=$ infinitive situation; arrow represents that there is a force directed at the dative participant.

Figure 1. The interpretation of the DI. 


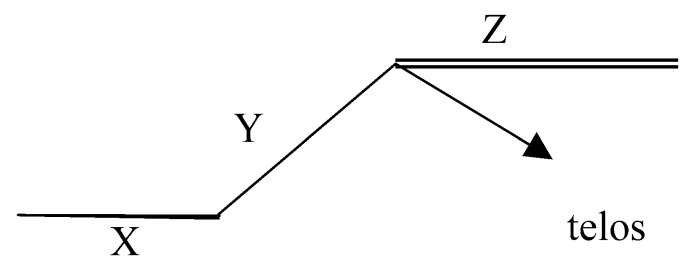

$X=$ scene before the start of the situation; $Y=$ time stretch associated with the situation in its progression ${ }^{2} \mathrm{Z}=$ new scene after the realization of the situation.

Figure 2. Perfective aspect.

The semantics of the Russian aspect has been a topic of active research and debate. I will not provide an overview of the vast amount of literature, but confine myself to a few more general remarks, relevant for the present discussion. The central feature expressed by the perfective which can be applied well to the aspect of the DI is change of situation (see for example Barentsen 1995, for discussion of he term смена ситуаций). See figure 2, for a simplified graphic representation.

As I will show, this idea of change of situation applies well to sentences that express the negation of an intended situation, typical of impossibility, but also to a number of other contexts that indicate a change such as speaker oriented/internal necessity, and embedding of the DI in specific contexts that presuppose the idea of a change. In all of the cases, the focus is on the reaching of the telos of the situation, resulting in situation $\mathrm{Z}$. As I will argue, there are a few contexts, where the occurrence of the perfective of the DI is better explained by the feature of 'discreteness' (see Barentsen 1995, for discussion of the term дискретность). This is for example the case in some perfective examples which express necessity with delimitative prefixes (no- and npo-) (see 4.2.6.).

In Russian, the imperfective aspect is typical of sentences where the idea of change is not present in reality, or known to be present in reality, but not taken into account in the conceptualization. An example of the latter case is the general factual meaning of the imperfective past tense, where it is possible to use the imperfective to refer to completed telic events (see Dickey 2000, 95-125 for a discussion of this use of the imperfective in Slavic). In the DI, the imperfective is typical of sentences that express external and ontic-epistemic necessity. In these cases, the intention of the dative subject to reach the telos of the situation is not taken into account, and the focus is on the engagement into the situation. See figure 3, for a simplified graphic depiction.

In this section, I have given an analysis of the meaning of the DI on the one hand, and the main properties of aspect, relevant for the DI, on the other. In the following sections, I will put these two things together and discuss the aspectual use of the DI. 


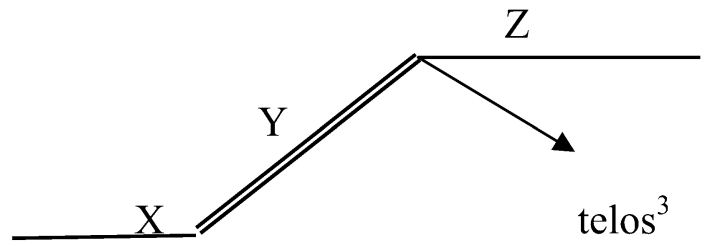

Figure 3. Imperfective aspect.

\section{IMPERFECTIVE CONTEXTS}

In the DI, the imperfective aspect is typical of declarative sentences that express external necessity (see Van der Auwera and Plungian 1998 for a description of the general modal terminology that I will use in this paper) $:^{4}$

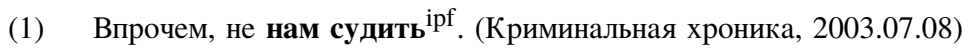
'By the way, it's not up to us to judge.'

(2) Тебе не сидеть ${ }^{\text {ipf }}$, тебе лежать ${ }^{\text {ipf! }}$ (В. Астафьев, Царь-рыба)

'You should not sit, but lie.'

(3) Та команда, в которой к концу турнира останется больше всадников, будет рыцарской конницей Нептуна. Ей сражаться ${ }^{\text {ipf }}$ с чудищами. (Трамвай, 1990) 'That team that will end up with the most riders at the end of the tournament will become Neptune's chivalrous cavalry. It's that team that will fight with the monsters.'

(4) Поглощение негативных выбросов модернизации - дело государства. Ему убирать ${ }^{\text {ipf }}$ социальную территорию. (Известия, 2002.09.12)

'The absorption of negative emissions of modernization is a task of the government. It's up to them to clean up the social territory.'

(5) Осенью им идти ${ }^{\text {ipf }}$ в первый класс. (Известия, 2002.03.22)

'This autumn they have to go to the first class.'

By using the DI, the speaker expresses that according to some norm, rule or script, the dative participant has to realize the infinitive situation. This meaning often occurs in a context of partial negation, contrast, emphasis of the dative, and sentences like (5), where it is expressed that a situation is due to occur at a particular moment in the future (here осенью 'this autumn'). The meaning of the DI is not identical to other modal expressions of participant external necessity such as надо, нужно, and әолжен, primarily because the modality is not expressed by a specific form, but an interpretation of a more abstract meaning (see Fortuin 2000, 343-345 for a more detailed discussion).

In sentences with negation of the infinitive situation, the DI expresses that there is no need to realize the infinitive situation: 


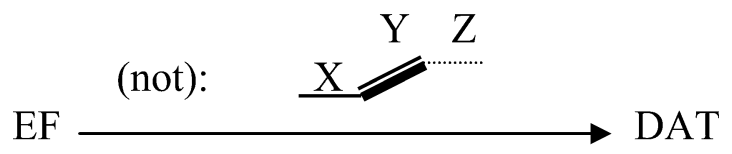

Figure 4. Imperfective DI.

(6) Нам не вставать ${ }^{\text {ipf }}$ рано.

'We don't have to get up early.'

The meaning of absence of necessity must be seen as an interpretation of the construction. The construction itself expresses that there is a force directed at the non-realization of the infinitive situation by the dative subject. In those contexts where the infinitive situation is seen as something negative, this is interpreted as signalling the absence of necessity, whereas in other cases, especially in the case of non-animate subjects, the construction is interpreted as expressing the inevitability that the infinitive situation will not occur (see Maurice 1995; Fortuin 2005 for a more thorough discussion).

The aspect of the infinitive in sentences that express external necessity is almost exclusively imperfective (exceptions are discussed in section 4.2.). The explanation for the imperfective aspect is that the first thing that comes to mind if a situation is imposed on an agent because of some rule, norm or script, is the occurrence of the situation as such or the engaging in the situation, and not the effects or consequences that the realization of the situation may bring about. See figure 4 for a graphic depiction, where the external force (EF) imposes the (not) engaging into the infinitive situation on the dative subject (DAT).

A correlation between imperfective aspect and external participant necessity can be found in other constructions as well. Take for example the necessitive imperative, which can also be seen as a syntactic expression of modality (see Fortuin 2000, 114-134 for an analysis of the semantics of this form):

(7) Мы плати ${ }^{\text {ipf }}$ за купе, а им оно бесплатно. (О. Павлов, Карагандинские девятины)

'We have to pay for the compartment, and they get it for free.'

The use of the imperfective in such sentences can be motivated by the idea of a state that the subject is in, which is induced by an external force. In this respect, the necessitive differs from the DI, because the DI typically expresses that the imperative situation is to be realized because of some external force. This character of script modality is absent with the necessitive imperative. ${ }^{5}$

The use of the imperfective differs from sentences with specific modal forms that express (internal, external or deontic) necessity, for example нужно, надо, должен, or необходимо. In affirmative sentences with these forms, 
the infinitive complement of the adverb can occur both in the perfective and imperfective aspect, for example:

(8) Прежде всего вам нужно обратиться ${ }^{\mathrm{pf}}$ в милицию. (Известия, 2002.09.30) 'First of all, you have to go to the police.'

(9) Вам нужно обращаться ${ }^{\text {ipf }}$ с исковым заявлением в суд о принудительном обмене жилого помещения. (Вечерняя Москва, 2002.12.09)

'You have to take your writ to the court for the compulsory exchange of living quarters.'

By using the perfective aspect the speaker focuses on the realization of a single situation ('you should see to it that you end up at the police station'), whereas the imperfective focuses on the engagement into the situation, in abstraction from a single situation ('in such and such a situation, you should start doing this'). ${ }^{6}$ In sentences with a negation, notwithstanding the type of necessity expressed by the modal form, the imperfective aspect is chosen (see Paducheva 2006, 3).

In my view, the main reason why the aspectual use of these constructions differs from the DI is that in constructions with a modal adverb, the modality itself is expressed by a specific form. The aspect of these constructions is expressed by the infinitive, which functions as a complement of the modal form. The general pattern which can be observed is that the aspect of the infinitive focuses on the quality or extension of the realization of the infinitive situation. This differs from the DI, where the modal meaning is a specific interpretation of the infinitive predicate, and where the aspect plays an important part in determining which modality type is expressed. In the DI, the imperfective aspect brings about an interpretation where the infinitive situation as such is something that is forced upon the infinitive subject from the outside, not considering the possible intention of the subject to realize the situation, whereas a perfective aspect leads to a different modality type, namely impossibility (see section 4.1.).

In some sentences the DI does not express that there is a person who has to do something, but rather that the realization of the infinitive situation by the dative participant is inevitable, or due to occur. This interpretation is typical of sentences with inanimate subjects, or non-controllable situations of animate subjects:

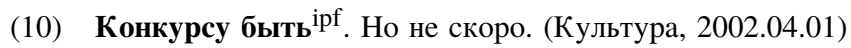

'There will be/is bound to be a competition. But not soon.'

(11) Мне умирать ${ }^{\text {ipf }}$.

'I will die/It is time for me to die/It is in the cards for me to die.'

(12) Но России скоро вступать ${ }^{\text {ipf }}$ в ВТО. (Известия, 2001.12.20)

'But soon the time will come for Russia to become a member of WTO.' 
(13) [Т]ы сам подписал себе смертный приговор. Теперь тебе не жить ${ }^{\text {ipf. }}$ (Mocковский комсомолец, 2003)

'You have signed your own death sentence. Now, you won't stay alive.'

Sentences like these can be said to express ontic-epistemic necessity. They express ontic modality because it is expressed that the way things go or are, is such that the infinitive situation will inevitably occur (see Fortuin 2000, 339-340 for a brief discussion of this term). Whether or not they can be classified as epistemic is, in my view, a matter of terminology. Van der Auwera and Plungian $(1998,81)$ define epistemic modality as follows: "It refers to a judgment of the speaker; a proposition is judged to be uncertain or probable relative to some judgment(s)." In the case of epistemic necessity, this concerns necessity because relative to some judgment, the situation will necessarily occur (in all possible worlds the situation occurs). If we follow this definition, the use of the DI under discussion can be seen as a case of epistemic modality, more specifically epistemic necessity. However, in contrast to forms that can have an epistemic interpretation such as English must, the idea of a force directed at the subject itself, is still present, hence the term ontic-epistemic necessity.

The aspect of the ontic-epistemic DI-construction is normally imperfective. This might seem surprising at first sight because the DI stresses the inevitable realization of the situation. Furthermore, Paducheva (2006, 4), and Wiemer (2001, 217) stress that in Russian there is an absolute correlation between epistemic modality and the perfective aspect. The imperfective aspect of the DI, however, shows that the speaker focuses on the fact that some action is imposed on the dative participant and that he will engage in the action. In the case of telic situations, the fact that the action will necessarily be realized is not highlighted. As such the DI differs from sentences with finite verbs such as предстоять ('be in store', 'have to') оr должен ('have to') for which the perfective infinitive is typical:

(14) Мне предстоит умереть ${ }^{p f}$.

'I have to die.'

(15) Я должен умереть ${ }^{\mathrm{pf}}$.

'I have to die.'

The construction with предстоять or должен allows the infinitive to focus on the realized situation that will occur (смерть), rather than on the force that makes the dative subject engage in the realization of the situation. Paducheva $(2006,4)$ argues that the perfective aspect in such sentences is triggered by the uncontrollable nature of the predicate. She sees a general correlation between the lack of control and the perfective aspect (e. g. the use of the perfective with imperatives). Although it may be true that there is indeed such a relation, ${ }^{7}$ it cannot account for the aspect of the DI, which is prototypically imperfective 
in sentences with an ontic-epistemic interpretation. Furthermore, there are also other expressions with uncontrollable situations, for example sentences with nopa, which can occur with an imperfective infinitive in sentences that are close in meaning to the DI:

(16) Мне пора умирать ${ }^{\text {ipf. }}$

'It is time for me to die.'

Here, again, the use of the imperfective stresses that the subject will engage in the situation. Note, furthermore that many ontic-epistemic uses of the DI are semantically quite close to an imperfective future tense, which merely states that there will be an occurrence of a situation somewhere in the future. The DI does the same, but expresses in addition that there is some (abstract) force which leads to this occurrence. Compare (12) with the following sentence:

(17) Но Россия скоро будет вступать ipf в ВТО.

'But Russia will soon (start negotiations to) become a member of WTO.'

One can therefore conclude that the necessitive use of the imperfective DI focuses on the occurrence of the situation as such which is due to occur. In contrast to the infinitive of modal forms, the aspect of the infinitive is not perfective, because it does not portray the goal (resultative situation) of the modal force. In the DI, the use of the perfective points at an intention of the infinitive subject to realize the infinitive situation, as will be discussed in the next section.

\section{PERFECTIVE CONTEXTS}

\subsection{Negation of intended situation (impossibility)}

The perfective aspect is typical of sentences that express (internal/external) impossibility:

(18) Без такой помощи им не выжить ${ }^{p f}$. (Российская газета, 2003.05.15) 'They can't survive without that help.'

(19) В одиночку мне не справиться ${ }^{\mathrm{pf}}$ с этим заданием[.] (Трамвай, 1991) 'I can't cope with that task by myself.'

(20) В одной берлоге двум медведям не ужиться ${ }^{\mathrm{pf}}$. (Независимая газета, 2003.06.16)

'Two bears won't succeed living in one lair.'

(21) Так или иначе, любой начинающей певице не обойтись ${ }^{\text {pf }}$ без профессионального и умного продюсера. (Аргументы и факты, 2001.03.07)

'Anyway, any beginning singer can't cope without a professional and wise producer.'

(22) Ей необходимо как можно больше времени проводить со своим хозяином [...]. И тогда преданней существа вам не найти ${ }^{\mathrm{pf}}$. (Аграрный журнал, 2002) [about a dog] 


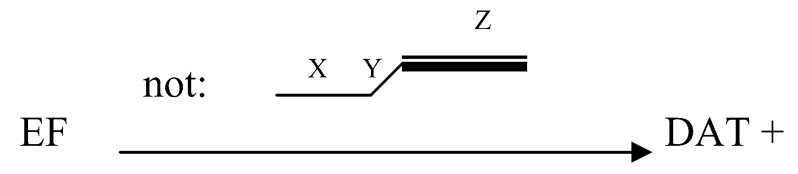

Figure 5. Perfective DI.

'It is necessary that it [the dog] spends as much time as possible with its owner. And then you won't be able to find a creature that is more faithful.'

(23) Но мне не ответить ${ }^{\text {pf }}$ на этот вопрос - я вообще в Бога не верю, атеист. (Вечерняя Казань, 2003.01.09)

'But I can't answer that question - I do not believe in God, I am an atheist.'

These sentences presuppose a subject that has an intention to fully realize the infinitive situation, but which is blocked in the realization of this situation. ${ }^{8}$ The impossibility expressed by the DI also has an ontic character because it is expressed that, because of particular circumstances, the intended situation won't occur. Nevertheless, one cannot classify sentences with a negation and a perfective aspect as epistemic (see for example Wiemer 2001 for such a classification), since they differ from actual ontic-epistemic sentences like (11) exactly because of the presence of an intention to realize the situation (which is blocked). Compare (11) with the following sentence: ${ }^{9}$

(24) Мне не умереть ${ }^{\mathrm{pf}}$ здесь.

'I cannot die here.'

The use of the perfective aspect runs parallel to the necessary presence of an intention for the situation, which is part of the meaning of possibility as such (see for example Talmy 1985, and Wierzbicka 1987, for the notion of intention or wish in relation to the notion of possibility). The negated perfective aspect focuses on the non-reaching of the natural or imposed end point (telos) of the situation, strived for by the subject, or attributed to the subject. ${ }^{10}$ See figure 5 for a graphic representation, where the external force (EF) imposes the the nonreaching of the telos and the resulting state $(Z)$ of the infinitive situation, on the dative subject, which has an intention to realize the infinitive situation (DAT + ).

Are there other constructions or forms where we find a similar correlation between negation of possibility and the perfective aspect? There is indeed some evidence that the correlation between the perfective aspect and the impossibility reading is not a typical trait of the DI, but occurs in other constructions as well. In order to show this, I will first discuss the aspect of the infinitive with the modal forms можно/нельзя and (не) мочь.

In sentences with explicit modal forms and negation (не мочь/нельзя), a correlation can be perceived between the perfective aspect and an (internal/external) impossibility reading (Rappaport 1985; Rassudova 1968; Wiemer 2001). 
Sentences with a perfective express the (internal/external) impossibility to reach the telos of the situation because of specific external or internal circumstances, whereas sentences with an imperfective express prohibition (deontic possibility), or the evaluation of the speaker that it is not a good idea ('one shouldn't', 'it makes no sense', etc.) to engage in the realization of the situation:

(25) Сегодня в Туркмении нельзя найти ${ }^{\mathrm{pf}}$ ни одного обиженного или преследуемого русского человека. (Независимая газета, 2003.06.30)

'Today you can't find one single offended or persecuted Russian person in Turkmenistan.'

(26) Например, нельзя читать ${ }^{\text {ipf }}$ детям много книг, не соответствующих их возрасту. (Домовой, 2002.02.04)

'For example, you may not read many books to children which are not suitable for their age.'

The aspect in such contexts can be explained as follows. The perfective focuses on the fact that the participant is not able to reach the telos, even if he wants to, whereas the imperfective focuses on the fact that the participant is supposed not to engage in the situation. A somewhat different explanation is given by Paducheva (2006), who argues that in order to say that the action as a whole is forbidden, it is sufficient to say this about the activity that leads to this result (cf. Rappaport 1985).

It must be remarked that there is not full correspondence between the imperfective aspect and a prohibition reading. Consider the following example with an imperfective aspect and an (external) possibility reading:

(27) Когда больше нельзя было скрывать ${ }^{\text {ipf }}$ беременность, Валерия Константиновна уехала в Москву. (Proeme 2003, 93)

'When she could no longer hide her pregnancy, Valerija Konstantinovna went to Moscow.'

Here, the use of больше нельзя focuses on impossibility to continuate the realization of the infinitive situation. For this the imperfective is a more suitable candidate than the perfective. ${ }^{11}$

An imperfective aspect is also used to indicate iteration with a (internal/external) possibility reading, for example:

(28) Он не может покупать ${ }^{\text {ipf }}$ вам хлеб. (Paducheva 2006, 1)

'He can't (regularly) buy you bread.'

The aspectual use of affirmative sentences differs from negative sentences. According to Paducheva $(2006,1)$, modal forms that are used to express (internal or external) possibility or impossibility occur in the perfective aspect:

(29) Ты можешь доехать ${ }^{p f}$ до вокзала на этом автобусе.

'You can reach the station with this bus.' 
Table 1. Aspect and modality type with forms of possibility/permission

\begin{tabular}{lll}
\hline & + Negation & - Negation \\
\hline Perfective & Impossibility & Possibility/Permission \\
\hline Imperfective & $\begin{array}{l}\text { Prohibition (impossibility in the context } \\
\text { of iteration or markers such as } \\
\text { больше не) }\end{array}$ & $\begin{array}{l}\text { Permission/Possibility, e. g. in the case } \\
\text { of iteration, specific verbs indicating } \\
\text { permanent possibility/permission }\end{array}$ \\
\hline
\end{tabular}

However, the use of an imperfective infinitive is possible in order to indicate iteration (Paducheva 2006), or to indicate a general capacity with verbs where the reaching of a specific telos is not important:

(30) Компьютер может читать ${ }^{\text {ipf }}$ мысли обезьян. ${ }^{12}$

'This computer can read the mind of monkeys.'

This shows that the correlation between (internal/external) possibility or impossibility and the perfective aspect is much stronger in the DI than in other modal constructions.

In sentences that express permission (deontic possibility) the perfective aspect is used:

(31) И определить наконец сумму наличной валюты и прочих товаров, которую то или иное лицо может вывезти ${ }^{\mathrm{pf}}$ за границу. (Известия, 2002.02.01)

'And finally to determine the amount of cash money and other goods, that one is allowed to bring abroad.'

But, again, the speaker may also use an imperfective:

(32) Согласно документу [...] правительство может привлекать ipf до 10260 военнослужащих. (Зарубежное военное обозрение, 2004.10.25)

'According to the document the government may recruit 10260 military personnel.'

In table 1 an overview is given of the relation between aspect and modality with можно/нельзя and (не) мочь.

The discussion of the aspectual properties of infinitives with можно/нельзя and (не) мочь leads to the following conclusions. Although there is a correlation between the use of the perfective aspect and a (internal/external) possibility reading, the perfective aspect is also used in affirmative sentences to express permission (deontic possibility). There is also no absolute correlation between (internal/external) possibility and the perfective aspect, because the possibility reading also occurs with the imperfective aspect, for example in contexts of iteration. If we look at table 1 , there is only one absolute correlation: negative sentences with a perfective aspect can only be interpreted as cases of impossibility (not prohibition). 
Note, however, that there is no general correlation in Russian between negation and perfective aspect and (internal/external) possibility. A counterexample to this relation is the necessitive imperative, which expresses prohibition (deontic impossibility), rather than (internal/external) impossibility in sentences with negation and a perfective aspect (although in some examples both interpretations may be at stake):

(33) В переднем вагоне скучно и хмурно и на ногу никому не наступи ${ }^{\mathrm{pf}}$. (Зощенко, На живца)

'In the first railway carriage it is dull and depressing, and you may not even step on anyone's foot.'

The interpretation of permission (deontic possibility) only occurs in negative contexts:

\footnotetext{
* и на ногу кому-нибудь наступи ${ }^{\mathrm{pf}}$.

Supposed to mean: 'you may step on someone's foot.'
}

This can be compared to the DI, which typically expresses (internal/external) impossibility, and only expresses possibility in specific contexts (see below). ${ }^{13}$ Like in the DI, the perfective aspect is sustained by the negation, more specifically by the idea of blocking the full realization of an intended situation (even on a single event). However, unlike the DI, the specific character of the modal gets the character of prohibition because of the general meaning of the necessitive imperative. More specifically, the use of the imperative presupposes a more clearly defined force, as such triggering a prohibitive reading, whereas the idea of a modal force in the DI has a more abstract character (circumstances or an internal property of the subject result in the non-occurrence of the situation). In the DI, the interpretation of absence of deontic possibility (prohibition) does not occur. ${ }^{14}$ Sentences with negation and a perfective aspect are interpreted as cases of impossibility, whereas sentences with negation and an imperfective aspect are either interpreted as cases of absence of necessity or cases of onticepistemic necessity, expressing that a particular situation will not occur. See figure 6 for an overview of the relation between aspect and modality in negative contexts with the DI, modal forms, and the necessitive imperative (Nec).

I have argued that the perfective aspect of the DI points at a (real or potentially attributed) intention of the subject to realize the situation, which is blocked by internal or external circumstances, leading to the non-reaching of the telos of the situation. As I have argued, there are also other forms where we find a similar relation between aspect and modality, but there are also differences which have to be attributed to the specific semantics of these constructions. I would like to claim, though, that the correlation between the negation of an intended situation and the perfective aspect has a parallel in the case of non-modal constructions 
DI

$\rightarrow$ Ipf: absence of necessity/non-occurrence (ontic-epistemic use)

$\longrightarrow$ Pf: impossibility (external/internal)

мочь $\longrightarrow$ Ipf: prohibition (deontic impossibility)

Nec $\longrightarrow$ Ipf: not attested

$\triangle$ Pf: prohibition (deontic impossibility), rather close to external impossibility

Figure 6. Relation between aspect and modality in negative contexts.

as well. Take for example the perfective aspect in past tense sentences like the following:

(35) Дубчек неоднократно писал Горбачеву, но тот не ответил ${ }^{\mathrm{pf}}$ ни на одно письмо. ${ }^{15}$

'Dubček wrote to Gorbačev repeatedly, but he did not answer to a single letter.'

The perfective aspect focuses on the non-reaching of the telos of the expected situation. This can be compared to the DI: the participant wants to reach the telos (change of situation), but is blocked, or put differently, there is an initial idea that a particular situation will or could occur, but this idea is denied. One could therefore speak of an epistemic negation, that is, the expectation that the situation will occur is denied, triggering the perfective which focuses on non-realization of the situation.

Note, that [negation $+\mathrm{V}_{\text {perfective }}$ ] does not always presuppose an intended situation. In the case of the directive imperative, the imperfective aspect often points at a prohibition ('may not/should not engage in the situation'), whereas the perfective aspect is typical of uncontrollable and undesirable situations:

(36) Смотри, не упади ${ }^{\mathrm{pf}}$.

'Be aware not to fall.'

Here, it seems, the perfective focuses the attention on the non-reaching of the unwanted telos, which may very well occur: 'Take precautions not to end up in the situation X.' The imperfective expresses a meaning where the speaker directs the addressee not to engage in the realization of the imperative situation (see figure 7). ${ }^{16}$

As I already mentioned, the interpretation of impossibility in declarative uses of the DI is foremost restricted to sentences with negation. It also occurs in non-negated sentences in a few specific contexts, such as partial negative forms

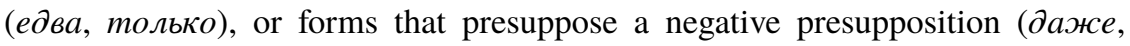




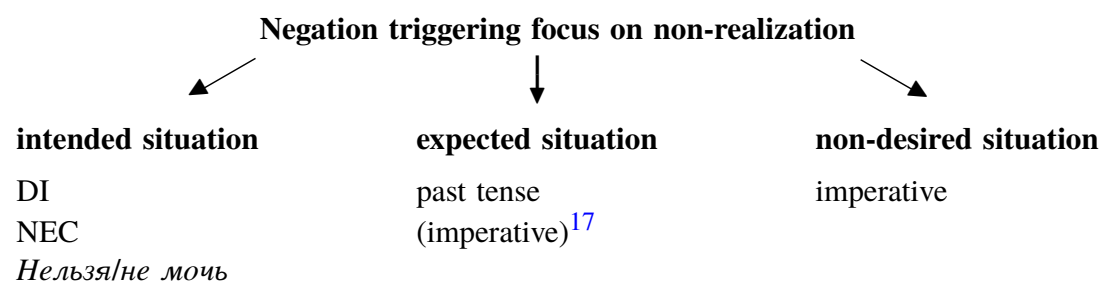

Figure 7. Relation between perfective aspect and negation.

contrastive sentences), and more frequently in interrogative sentences with an interrogative pronoun or adverb.

(37) Мозжухину войти ${ }^{\mathrm{pf}}$ даже в пятерку сильнейших. (Вечерняя Москва, 1971.06.21)

'Mozžuxin is even able to become one of the five strongest.'

(38) Соколок вокруг башни круг дает большой, а ласточка - малый. Ей скорей обернуться ${ }^{\mathrm{pf}}$. (В. Бианки, Лесные были и небылицы)

'The little falcon can fly around the tower in a wide circle, but the swallow makes a small circle. It can, however, turn around more quickly.'

(39) Как нам понять ${ }^{\mathrm{pf}}$ наших родителей, других людей? (Трамвай, № 5, 1990) 'How are we to understand our parents and other people?'

In Fortuin $(2000,389-408 ; 2005)$ an overview is given of the different contexts. In these contexts, we also find an initial information state that not $\mathrm{X}$ is the case, which is negated. As such, the aspectual choice can be explained in similar terms as sentences with negation. ${ }^{18}$ This means that the ability reading of the DI differs from the ability reading of other syntactic expressions of possibility, more specifically the perfective present, which may express possibility in specific contexts without negation:

(40) Он без проблем решит ${ }^{\mathrm{pf}}$ такую задачу.

'He solves such a sum without any problem.'

In such sentences, the possibility reading has the character of a future tense in a conditional context: 'if you give him this problem, he will solve it' (see Barentsen 1998, who links this interpretation to the feature of sequential connection, part of the meaning of the perfective in Russian). ${ }^{19}$

\subsection{Necessity (in perfective contexts)}

As I have argued, in the DI, the interpretation of necessity is typically correlated with the imperfective aspect. There are, however, a number of contexts where a perfective DI is interpreted as a case of necessity. What all these uses have in common is that the DI focuses on the idea of a change of situation, because of the relation with another situation. In this section, I will discuss these uses. 


\subsubsection{Participant internal necessity/Goal directedness}

The Russkaja Grammatika (1980, 374) gives a perfective example of the DI with the meaning of субъективная необходимость и желаемость ('subjective necessity and wish'):

(41) Вы зачем пришли? - Мне поговорить ${ }^{p f}$ с учителем.

'Why are you here? - I need to speak to the teacher.'

A similar example is given below, with the same verb (поговорить) and also a first person:

(42) Что прикажете? - Мне поговорить ${ }^{p f}$ с вами. (Л. Толстой, Дьявол)

'What do you wish? - I need to speak to you.'

It can be argued that the perfective is correlated with the internal necessity of the DI in this sentence. By using the perfective aspect the focus is on the change of situation and the desired resulting situation. Note, however, that the feature of participant internal necessity itself is insufficient to trigger a perfective aspect. Sentences like the following are therefore unacceptable exactly because they occur in isolation, without phrases like Вы зачем пришли? оr Что прикажеme?:

(43) ?Мне уехать ${ }^{\mathrm{pf}}$.

Supposed to mean: 'I have to leave (and I want it).'

(44) 'Мне поговорить ${ }^{\text {pf }}$ с вами.

Supposed to mean: 'I have to speak with you (and I want it).'

Instead, the normal way to convey the meaning of participant internal necessity would be by using an explicit modal form such as хотеть, надо, нужно оr cmoum, and an infinitive.

In my view, the use of the perfective in both examples must be related to the larger syntactic structure in which the DI occurs. In both sentences, the DI is an answer to a question, and has a function similar to a complement or subordinate clause (cf. Я пришел (итобы) поговорить с вами). This suggests that the perfective aspect is at least partly triggered by the connection with the first part of the sentence. Besides this, the speaker oriented perspective, the participant internal necessity and the meaning of the lexical verb may play a part. To confirm this hypothesis, more examples are needed.

\subsubsection{Participant internal necessity/Context of 'division'}

The Russkaja Grammatika (1980, 374) gives one more example besides (41) of a perfective DI with the meaning of internal necessity: 
(45) В приемной много посетителей: одному подписать ${ }^{\mathrm{pf}}$ справку, другому подать $^{\mathrm{pf}}$ жалобу, третьему - увидеть ${ }^{\mathrm{pf}}$ председателя (газ.).

'There are many people in the waiting room: one needs a certificate, someone else wants to file a complaint, and another one wants to see the president.'

A clue that the perfective aspect is related to the meaning of participant internal necessity is that the imperfective is chosen in the case of external necessity, where the idea of a desired situation is absent. In such sentences, the situations that have to be realized are contrasted with each other, suggesting simultaneity:

(46) Каждому свое. Одним думать ${ }^{\mathrm{ipf}}$, другим умирать ${ }^{\mathrm{inf}}$. Но люди умирают не от отсутствия мыслей. Умирают от голода. (Н. Джин, Учитель)

'Everybody has his own destiny. Some are fated to think, others to die. But people do not die because of the absence of ideas. They die of hunger.'

(47) Так, наверное, заведено: одним - жить ${ }^{\text {ipf }}$ в тепле, другим - стынуть ${ }^{\text {ipf }}$ и мокнуть $^{\text {ipf }}$. (Г. Владимов, Три минуты молчания)

'This is probably how it should be: some are to live in warmth, others are to suffer from cold and rain.'

Note, however, that in contrast to the examples (41) and (42), the perfective use of the DI in sentences like (45) does not necessarily have to be sustained by the broader linguistic context. In the following perfective examples, the DI is not an answer to a question, and lacks the feature of goal-directedness:

(48) А у каждого радость своя, но тем не менее, это радость и удовольствие. Одному книгу почитать ${ }^{\mathrm{pf}}$, другому напиться ${ }^{\mathrm{pf}}$, третьему в поле поработать $^{\text {pf }}$ или помыть ${ }^{\text {pf }}$ свой любимый сарайчик. (Forum site) ${ }^{20}$

'Everyone has his own happiness, but none the less it's happiness and satisfaction. Some like to read a book, others like to drink a lot, and still others like to work in the field or wash their favorite little shed.'

(49) Оказалось, что в 'центре обслуживания абонентов' на малой Дмитровке штук 15 рабочих мест и 1 (ОДИН) человек, который по очереди решает проблемы всех пришедших абонентов. Одному СИМку поменять ${ }^{\mathrm{pf}}$, другому роуминг включить ${ }^{\mathrm{pf}}$, третьему тарифный план сменить ${ }^{\mathrm{pf}}$. (Weblog) ${ }^{21}$

'It turned out that in the 'service center for subscribers' on the Malaja Dmitrovka there are about 15 working places but 1 (ONE) person, that has to solve the problems of all the subscribers that have come one by one. One wants to change his SIM-card, the other wants to connect his roaming, a third wants to change the tariff.'

This suggests that the use of the perfective DI is sustained here by the contrastive context, and the connection with other participants to which a situation is distributed. In contrast to imperfective sentences like (48) and (49), the necessity of the different situations are not conceptualized as taking place at the same moment, but may take place one after another. 


\subsubsection{Conditional sentences with только ('just')}

The DI can get an interpretation of necessity in sentences with the restrictive particle только, where the DI can be seen as the first part of a conditional clause:

(50) Ему только ногой топнуть ${ }^{\text {pf }}-$ нефтяной фонтан забьет. (Г. Владимов, Шестой солдат)

'He just has to stamp with his foot, and he hits an oil gusher.'

These sentences express that for the realization of $\mathrm{Y}$, only $\mathrm{X}$ is necessary. The restrictive character is connected with the semelfactive character of the verb in combination with the meaning of только ('just'). Here, the perfective aspect is triggered by the conditional structure of the clause. The starting point is the realization of $\mathrm{Y}$, expressed by the second clause: if you consider the realization of $\mathrm{Y}$, than one has to perform X. Cases like these can be seen as examples of the so-called use of sequential connection, typical of the perfective aspect (see Barentsen 1998 for this term, and Dickey 2000, 26, 27 for a discussion of the similar feature of temporal definiteness). The same structure can be found in other constructions, for example with the predicative adverbs достаточно, cmoum:

(51) Ему достаточно ногой топнуть ${ }^{\mathrm{pf}}-$ нефтяной фонтан забьет.

'He just has to stamp with his foot, and he hits an oil gusher.'

\subsubsection{Sentences with a conjunction}

The DI occurs in sentences with a conjunction, for example a conjunction of anteriority, purpose or condition (see Fortuin 2000, 409-420 for an overview). In such sentences, the modality associated with the DI is similar to the modality of normal declarative sentences (see Fortuin 2006). However, because of the meaning of the conjunction, and the larger construction, the aspectual properties of such sentences differ from regular declarative DI sentences. A good example is the use of the DI with a conjunction of anteriority. In contrast to regular uses of the DI, the interpretation of participant external necessity and ontic-epistemic necessity occurs with the perfective aspect. Compare (11) with the following sentence with the conjunction перед тем, как ('just before'):

(52) Ты умрешь, Меер Бесконечный. Но перед тем, как вам умереть ${ }^{p f}$, скажите мне, - я интересуюсь это знать, - есть у нас советская власть или, может быть, ее нет у нас? (И. Бабель, Конец богадельни)

'You will die, Meer Beskonečnyj. But before it is time for you to die, tell me, I would like to know, do we have the soviet power, or perhaps, do we not have that power?' 
The use of the perfective has to do with the meaning of the conjunction, which expresses a moment just before a change is to occur (see Fortuin 2006 for an analysis). The same perfective aspect occurs in sentences without a dative subject. As such, the meaning of change overrides the imperfective aspect, prototypically correlated with the interpretation of necessity.

\subsubsection{Sentences with скоро and ontic-epistemic reading}

Although sentences expressing ontic-epistemic necessity prototypically occur with the imperfective aspect, there are rare examples with a perfective aspect:

(53) Им скоро стать ${ }^{p f}$ солдатами. (Rappaport 1985, 209)

'They will soon become soldiers.'

The perfective aspect in this sentence is connected to the use of the adverb скоро ('soon'), and the lexical meaning of the verb стать солдатами ('become soldiers'), which is typically associated with a single event without duration ('obtaining the rank of soldier'). Other uses with скоро are given below, all with non-controllable situations:

(54) И вот что он мне отвечал, когда я у него спросил о ее причине: мне скоро умереть $^{\text {pf; } ; ~ я ~ в и д е л ~ с в о и м и ~ г л а з а м и ~ с м е р т ь ~ м о ю . ~(В . ~ А . ~ Ж у к о в с к и и ̆, ~ Н е ч т о ~ о ~}$ привидениях (1848))

'And this is what he answered me when I asked him about her reasons: I will die [be dead] soon; I have seen my death with my own eyes.'

(55) Ты знаешь, что мне - скоро умереть ${ }^{p f}$. (А. Югов, Ратоборцы)

'You know, that I will die [be dead] soon.'

(56) Иван рассердился, грозил ему своим гневом, приказывал ему быть митрополитом. «Если меня и поставят, то все-таки мне скоро потерять ${ }^{\mathrm{pf}}$ митрополию [...]». (Н. И. Костомаров, Русская история в жизнеописаниях ее главнейших деятелей. Выпуск второй: XV-XVI столетия (1862-1875)) 'Ivan got angry, threatened him with his anger, as he ordered him to become the metropolitan. "If they make me a metropolitan, I will soon lose [be without] the metropolitan see [...]".'

The form скоро can easily be interpreted as expressing the idea of a change. In these examples the perfective aspect, together with скоро, focuses on the end point of a process ('be a soldier', 'be dead', 'having lost something'), by contrasting it with the present ('the current situation will soon be changed'). For this the use of the perfective is typical. A similar difference can be found in other constructions as well, for example in sentences where the infinitive is a complement of a finite verb. In such sentences скоро also triggers the perfective aspect with telic verbs, because it presupposes the idea of a change:

(57) Я хочу скоро начать ${ }^{\mathrm{pf}}\left[{ }^{?}\right.$ начинать $\left.{ }^{\mathrm{ipf}}\right]$.

'I want to start soon.' 
Note that in the DI with скоро the imperfective occurs as well, in contexts where the speaker wants to focus on the beginning of or engaging in a situation, for example:

(58) В конце концов, мне скоро умирать ${ }^{\text {ipf, }}$ и детей у меня нет. (В. Рыбаков, Гравилет 'Цесаревич')

'Finally, I will die soon, and I have no children.'

The data at my disposal suggest that, at least in the twentieth century, in the DI with скоро the use of the imperfective aspect is more common than the perfective aspect.

\subsection{6. Еще and specific 'Aktionsart'}

Maurice (1996) claims that the perfective aspect can be used in sentences with the particle eme ('still') in order to emphasize that the result of the action is wished, e. g.:

(59) Мне еще решить ${ }^{\text {pf }}$ задачу. (Maurice 1996, 119) 'I still have to solve a problem.'

She further argues that most speakers of Russian do not accept sentences with a perfective aspect and eme (Maurice 1996, 120, 142). I have in fact only attested two sentences, one with the perdurative prefix npo-, the other with the delimitative prefix no-:

(60) Видно, мне еще проискать ${ }^{\mathrm{pf}}$ его месяц, другой. (В. Т. Нарежный, Российский Жилблаз, или Похождения князя Гаврилы Симоновича Чистякова (1814))

'It's clear that I will have to look for him another whole month.'

(61) Ему еще пожить ${ }^{\mathrm{pf}}$, пока Колмаков с бюллетня не выйдет. (Л. Петрушевская, Казнь)

'He will only [lit. still] live until Kolmakov returns from leave.'

This suggests that the use of the perfective aspect is triggered by the need to express the specific semantics associated with these prefixes. In these sentences, the meaning of eme presupposes that a particular part of the infinitive situation has already occurred, and that there is a part or portion left that still has to occur. In Russian, the idea of a portion or part of a situation is associated with the perfective aspect, which presupposes the idea of a discreteness of a situation (Barentsen 1995), or totality which, in the case of delimitatives is interpreted as temporal bounding (Dickey 2000, 46). 


\subsubsection{Questions}

The DI may express necessity with a perfective infinitive in interrogative contexts with почему ('why'), or without question word (often with может 'perhaps'), usually with a first person:

(62) Почему мне уехать $\mathrm{pf}^{\mathrm{f}}$ заграницу? Это не то. ${ }^{22}$

'Why should I leave the country? That's not a solution.'

(63) Может, мне переехать ${ }^{\mathrm{pf}}$ в Москву? (Новый Мир, № 9, 2002)

'Perhaps, I should move to Moscow?'

In sentences with почему the speaker questions the idea that the dative subject should perform a certain situation. In sentences without interrogative adverb the speaker suggests to realize the infinitive situation, by asking whether the idea that the dative subject should perform a certain situation is a good idea. The perfective aspect is triggered in both usage types by the starting point that $\mathrm{X}$ might occur. The speaker proceeds from the idea that the realization of $\mathrm{X}$ is the right thing to do, and asks whether this realization is really a good idea.

\subsubsection{Infinitive complement}

The DI is used in sentences where it is dependent on a noun. In some sentences the dative functions both as part of the valency structure of the noun, and as the subject of the infinitive. This is the case in the following sentence where the dative of все (всем 'to everyone') is assigned by the noun приказ ('order') (приказ всем - 'an order to everyone'), but at the same time functions as the subject of the infinitive:

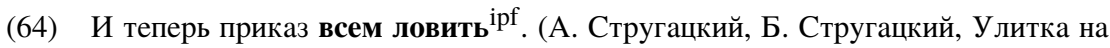
склоне)

'And now an order to everyone to catch it.'/'And now an order that everyone must catch it.'

Such cases are similar to constructions where the infinitive functions as complement of a finite verb: Приказал всем ловить ('ordered everyone to catch'). With other nouns, for example nouns of thought, the dative cannot be seen as part of the regular valency structure of the noun. In such sentences, the dative can only be interpreted as subject of the infinitive:

(65) Какой смысл вам молчать ${ }^{\text {ipf }}$ ? Будем говорить? (Ю. Семенов, Семнадцать мгновений весны)

'What reason is there for you not to talk? Shall we talk?'

In some sentences of this type we find a perfective infinitive, even though the modality associated with the DI is closer to necessity than possibility: 
(66) Пришло время тебе узнать ${ }^{\mathrm{pf}}$ о сексе. (Домовой, 2002.03.04)

'The time has come for you to know about sex.'

(67) Вертинский не раз говорил, что, когда придет время ему умереть ${ }^{\mathrm{pf}}$, он не хотел бы этого дома[.] (Л. Вертинская, Синяя птица любви)

'Vertinskij never said that when the time would come for him to die, he didn't want that at home.'

Again the aspectual usage of the infinitive is triggered by the syntactic context, and similar to sentences without dative, for example:

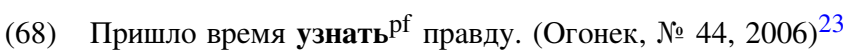

'The time has come to discover (lit. know) the truth.'

Here, the speaker expresses that it is the right time for the realization of the infinitive situation. By using the perfective the speaker focuses on the change of situation: proceeding from a state of not knowing to a state of knowing. There is, however, no one-to-one correspondence between the perfective aspect and this construction type, since imperfective uses also occur:

(69) Пришло время Никите возвращаться ${ }^{\text {inf }}$ на больничную койку, а Шашлыку - собираться в командировку. (Столица, 1997.12.22)

'The time had come for Nikita to return to his hospital bed, and for Šašlyk to go on a business trip.'

(70) Но это футбол, и настало время мне принимать ${ }^{\text {ipf }}$ решение, каким бы трудным оно не было. (Футбол-4//Форум forumsport.ru, 2005)

'But that is football, and the time had come for me to make a decision, no matter how difficult it would be.'

By using the imperfective, the speaker may focus on the engaging in the situation ('the time has come to start doing something'), whereas the perfective expresses a change of situation, and focuses on the result of this change ('the time has come to be in this situation').

\subsection{External force is the speaker}

The perfective aspect is also typical of sentences where the external (modal) force is the speaker. In such sentences, the speaker takes an egocentric point of view, and conceptualizes the resultative state desired by him. Different kinds of such constructions can be distinguished:

(i) directives

(ii) sentences with $6 b l$

(iii) sentences with все and только and бы

(iv) sentences with только without бы

I will discuss them below. 


\subsubsection{Directives}

A perfective infinitive occurs in directive sentences:

(71) Всем встать ${ }^{p f}$ ! (В. Ерофеев, Вальпургиева ночь, или Шаги командора) 'Everyone stand up!'

Although infinitive directives prototypically occur without subject, the dative can be used with forms like все. Cases such as these are similar to regular (non-negated) imperatives, where the speaker focuses on the desired results of a single action.

A directive meaning is also part of sentences like the following where the speaker directs himself (or others with him) to realize a situation. In both examples we find a similar structure $\left[\mathrm{INF}_{\text {verb of movement }}+u+\mathrm{DAT}_{\text {focus }}\right]$ :

(72) Поехать ${ }^{\mathrm{pf}}$ и мне, узнать, что там такое, - сказал Дубов. (Russkaja Grammatika 1980, II: 374/A. Фадеев)

'I should go myself too, to find out what is going on there, Dubov said.'

(73) Пойти ${ }^{\mathrm{pf}}$ и нам собираться. (В. Короленко, Черкес)

'We should leave and come together too.'

\subsubsection{Sentences with бы}

The perfective infinitive occurs in sentences with the particle $\sigma b l$, that express a wish of the speaker that the infinitive situation will be realized:

(74) Отдохнуть ${ }^{\text {pf }}$ бы брату. (Mets 1985,385 )

'My brother should rest.'

Note, that such sentences are not exclusively perfective:

(75) Отдыхать ${ }^{\text {ipf }}$ бы тебе чаще! (Mets 1985, 358)

'You should rest more often.'

In the case of the perfective the emphasis is placed on the positive consequences of the realization (reaching of the telos) of the infinitive situation, whereas in the case of the imperfective aspect the emphasis is placed on the occurrence of the situation qua situation, the fact that the dative participant is to engage in the infinitive situation, or the circumstances of the realization of the situation (иаще). Cases like these show similarities with the use of the directive imperative in non-negated contexts, where we find a similar aspectual pattern (see Rassudova 1968).

Sentences with negation and $\sigma b l$ behave differently from affirmative sentences with respect to their aspectual use. In sentences with a perfective infinitive (usually without dative) the speaker considers a hypothetical state of affairs that would be bad for him and expresses an apprehension that this bad thing might happen: 
(76) Не отставай, не опоздать ${ }^{p f}$ бы к обеду. (Б. Пастернак, Посторонний) 'Come on, move, we don't want to be late for dinner.'

Sentences like these express a desire to do something to prevent the undesirable state of affairs. The aspect of the construction under discussion can be motivated as follows. The speaker focuses on the absence of the change of situation, since the effect of that change is associated with negative consequences. For such a reading the perfective aspect is typical (cf. the use of the perfective imperative with negation, which is used with regard to non-desirable uncontrollable situations).

The perfective aspect also occurs in sentences that express that if things would have been different, the occurrence of the infinitive situation would have been impossible, for example:

(77) И проживи Иван Калита хоть сто лет, не накопить ${ }^{\text {pf }}$ бы ему без иноковой помощи средств[.] (А. Лазарчук, Михаил Успенский. Посмотри в глаза чудовищ)

'Even if Ivan Kalita had lived for a hundred years, without the help of the monks he would not have been able to gather all the means.'

For the occurrence of the perfective the same explanation can be given as for the occurrence of the perfective in negated sentences without $\sigma b l$ (see 4.1.).

Instances of the DI with negation, $\sigma b l$ and the imperfective aspect express the necessity not to perform an action. In some sentences the speaker expresses his wish that a past undesirable situation would not have occurred, but that, instead, the infinitive situation would have occurred. Such sentences may occur in a conditional structure as in (78), but the positive consequences of the nonrealization of the infinitive situation may also be left implicit, as in (79):

(78) И не уезжать ${ }^{\text {ipf }}$ бы им отсюда никуда, - тогда, быть может, судьба всей семьи обернулась бы совсем иначе[.] (С. Аллилуева, Двадцать писем другу) 'They should not have left from here, then, perhaps, the faith of the family would have been totally different.'

(79) И не глядеть ${ }^{\text {pf }}$ бы ему в ту сторону, [...] но помощь оттуда что-то не шла и не шла, и поэтому он все-таки туда поглядывал. (Б. Васильев, А зори здесь тихие)

'And he should not have looked in that direction, but somehow no help was coming from there at all, and therefore he decided to look anyway.'

In the case of a situation that has already occurred, the completion of the situation is a given fact; in this case the speaker focuses on the occurrence of the situation qua situation, and uses the imperfective aspect. As such, these uses are similar to the use of the imperfective in declarative sentences without $6 \mathrm{bl}$, where we also find a correlation between the imperfective aspect and the meaning of necessity (see section 3.). ${ }^{24}$ 
Table 2. Relation between aspect and interpretation in the DI with $\sigma_{b l}$

\begin{tabular}{|c|c|c|}
\hline & + Negation & - Negation \\
\hline Perfective & $\begin{array}{l}\text { wish that a non-desirable situation } \\
\text { will not happen (cf. negated } \\
\text { perfective imperative) } \\
\text { impossibility in counterfactual world } \\
\text { (cf. use of DI in negated perfective } \\
\text { sentences without } \sigma \mathrm{bl} \text { ) }\end{array}$ & $\begin{array}{l}\text { wish of the speaker for change } \\
\text { of situation (telos) (cf. use of the } \\
\text { perfective imperative in non-negated } \\
\text { contexts) }\end{array}$ \\
\hline Imperfective & $\begin{array}{l}\text { necessity not to engage in a situation } \\
\text { in a counterfactual world (cf. use of } \\
\text { DI in negated imperfective sentences } \\
\text { without } \sigma \text { l) } \\
\text { advice not to engage in the } \\
\text { situation (cf. use of the imperfective } \\
\text { imperative in negated contexts; use } \\
\text { of sentences with луише) }\end{array}$ & $\begin{array}{l}\text { wish of the speaker that the situation } \\
\text { will be realized, with a focus on the } \\
\text { circumstances of the realization or in } \\
\text { the context of iteration (cf. use of } \\
\text { the imperfective imperative in non- } \\
\text { negated contexts) }\end{array}$ \\
\hline
\end{tabular}

In sentences with an imperfective infinitive and second person it is expressed that it is better not to engage in the realization of the infinitive situation:

(80) Не уходить ${ }^{\text {ipf }}$ бы вам сегодня [...] (А. Стругацкий, Б. Стругацкий, Трудно быть богом)

'You should not leave today.'

In sentences where the infinitive situation is associated with a future event, the speaker focuses on the fact that the dative participant should not engage in the infinitive situation and uses the imperfective aspect. Such sentences show close similarities to negated imperfective imperatives (не уходи $u^{\mathrm{ipf}}$ сегодня 'don't go today') or such sentences with луише ('better'), where the imperfective aspect is also used:

(81) А только лучше вам не уходить ${ }^{\text {ipf }}$ [...] (А. Стругацкий, Б. Стругацкий, Трудно быть богом)

'It's just that you better not leave today.'

In table 2, on overview is given of the different interpretations of the DI in sentences with $\sigma b l$, and the relation with aspect. The general conclusion that one may draw is that the aspectual use of the DI with 6 bl shows similarities both to the use of the imperative, and to the use of the DI without 6

\subsubsection{Sentences with все and только and бы}

The DI may also be used in sentences with все ('all') or только ('just'), where the dative participant is the external force:

(82) Тебе бы все пить ${ }^{\text {ipf }}$ да жрать ${ }^{\text {ipf }}$. (Maurice 1996, 162)

'If it were up to you, you would eat and drink all the time.' 
(83) Накинув на голову шлем, Аурел тронул мотоцикл с места и молнией вынесся со двора. Теперь ему бы только вырваться ${ }^{p f}$ на трассу, ведущую к перегону. $^{25}$ (В. Васильев, Сердца и моторы)

'After putting on his helmet, Aurel moved his motorcycle from its place and took off from the courtyard, as fast as lightning. Now he only wanted to break away and go on the route.'

The infinitive may be imperfective or perfective. The imperfective aspect is typical of cases where the speaker disagrees with the kind of behavior, indicated by the infinitive, whereas the perfective aspect is typical of cases where the speaker identifies with the wish of the dative participant to realize a single event. In (82) this is correlated to the use of $8 c e$, which indicates a permanent situation, whereas in (83) we find the use of meneps ('now'), which, in combination with только, focuses on one single desired situation.

Note that the form только also occurs in sentences where it indicates a permanent desire of the dative subject ('the only thing you want to do (all the time) is this'). For such cases, the imperfective aspect is more typical than the perfective.

\subsubsection{Sentences with только without бы}

Finally, DI is used in sentences with the restrictive particle только without бь to indicate the whish of the speaker/dative subject:

(84) Мне только чай взять ${ }^{\mathrm{pf}}$. (М. Задорнов, Я никогда не думал ...) 'I only have to buy some tea.'

(85) Нам только ночку переспать ${ }^{p f}$, промокли мы до нитки. (В. Бугаенко, Математический кружок. 9-й класс)

'We only want to/have to sleep for one night, as we are soaked to the skin.'

Here, the perfective aspect is triggered both by the speaker oriented (internal) necessity, and the use of только ('only'), which focuses on one single, small event. The speaker oriented necessity presupposes that the speaker wants a change of situation because this change will result in a new situation desired by him. In addition, полько presents the situation in which the dative subject should engage as small. This character of quantifiability suits the meaning of the perfective aspect well, since the perfective aspect typically conceptualizes the situation as something discrete, with clear boundaries (cf. the use of the perfective DI with eme and delimitatives).

\section{GENERAL CONCLUSION}

As I have shown, aspect is an important factor in the interpretation of the DI as belonging to a specific modality type (necessity, impossibility, etc.). The 
aspectual choice of the DI differs, however, considerably from constructions with explicit modal forms (modal adverbs and modal infinite verbs). This has to do with the different semantic-syntactic structure of these expressions. Whereas with modal forms the modality is expressed by a particular form, and the infinitive functions as a complement of the predicate, in the DI the modality is syntactically derived, and the aspect of the DI partly determines the modality of the construction.

A general conclusion that one may draw from this analysis is that it is important to look at the specific meaning and syntactic structure of forms and constructions in explaining aspect. Although cross-linguistically defined notions of modality such as internal, external or epistemic necessity may sometimes be helpful in the analysis of specific forms, they cannot be seen as conceptual notions that correlate with specific forms in the linguistic system. In the end, the aspectual usage of the DI must be analysed in terms of the interaction of the general meaning and function of aspect in Russian, which can be explained in terms of conceptually basic notions such as change and discreteness and the specific semantics and syntax of the DI, which also expresses the conceptually basic scene of a force directed at the realization of the infinitive situation.

This is not to say though, that the linguistic mechanisms that lead to a correlation between aspect and a specific modality type are an idiosyncratic phenomenon of the DI. As I have shown, they are largely motivated by other constructions in the linguistic structure of Russian, both modal and non-modal.

In the DI, the imperfective aspect is correlated with ontic-epistemic and external necessity. In sentences with negation it expresses absence of external necessity, or the ontic-epistemic necessity of a negative situation (' $x$ will not occur'). The imperfective signals that no intention of the dative subject to reach the telos of the infinitive situation is considered. The correlation between imperfective aspect and necessity runs counter to a general tendency in Russian to use the perfective with expressions of necessity, especially in the case of forms that express epistemic necessity. I have shown that the occurrence of the imperfective aspect can, however, be found in other syntactic expressions of necessity. An example is the necessitive imperative, which may express external necessity. Examples of the use of the imperfective aspect with forms expressing epistemic modality are rarer. I have, however, pointed out that the epistemic modality associated with the DI is close to the meaning of the imperfective future tense.

In the DI, the perfective occurs most frequently in sentences with negation, expressing impossibility. The use of the perfective signals that a tendency or intention of the dative subject to reach the telos of the infinitive situation is considered. As I have shown, this tendency has a parallel in other constructions, both modal and non-modal. One may in fact speak about a general tendency in 
Russian to use the perfective with negation if the realization of the situation is somehow put forward as salient, for example because it is expected or intended. I have suggested that the use of the perfective with negative imperatives may be part of the same tendency: by using the perfective the speaker focuses on the undesired situation that the addressee is to avoid.

The perfective is also used in affirmative sentences where the speaker can be seen as the external modal force. In such sentences the speaker takes an egocentric point of view, and portrays the situation desired by him, as such presupposing a change of situation resulting in that desired situation. Finally, the perfective aspect with a necessity interpretation also occurs in a number of affirmative contexts, where the broader (syntactic) context presupposes the idea of a change, as such triggering the perfective aspect. These contexts overrule the general association between the necessity reading and imperfective aspect, typical of the DI in regular declarative sentences.

\section{NOTES}

1 I will use the term situation as a cover term for the different temporal concepts expressed by verbs (states, actions, events, etc.). I will use the term dative subject to refer to the potential subject of the infinitive situation, which is expressed by the dative noun. As I will argue, the interpretation of the dative as a dative subject presupposes the idea of a force. One can always speak of an external force because the force cannot be identified with the dative subject itself. In the case of sentences expressing external necessity, the concept of an external force is clear because the primary impulse to create the situation does not come from the dative subject, but from another person, a societal norm, a rule or a script. In the case of sentences expressing impossibility, one can speak of an external force because external (physical or abstract) circumstances block the realization of the infinitive situation. In the case of sentences expressing internal necessity, one can speak of an external force because the urge of the dative subject to create the situation is conceptualized as the result of external factors. Finally, in sentences that express a wish (with the particle $6 u l$ ), the speaker is the external force. In those sentences where the speaker is coreferential with the (dative) infinitive subject, the speaker is conceptualized both as external force and potential subject of the infinitive situation.

2 In this figure, the transition from $\mathrm{X}$ to $\mathrm{Z}(\mathrm{Y})$ is depicted as something that takes time, but there are of course situations where this transition is instantaneous (Vendler's achievements).

3 Of course, the telos is absent in the case of atelic verbs.

4 All the examples are taken from the Национальный корпус русского языка, unless indicated otherwise.

5 An association between a script meaning and an imperfective also occurs in the case of the imperfective past tense when it is used to indicate an action that is to occur according to plan. Below, two examples with завтра ('tomorrow') and an imperfective past tense are given:

(a) Утешает одно: завтра я собиралсяірf в Ульяновск; вот было бы интересно потерпеть аварию где-нибудь под Саранском! (За рулем, № 2, 2004)

'There is one relief: the next day (lit. tomorrow) I would go (lit. went) to Ul'janovsk; so it would be interesting to have an accident somewhere near Saranskij.'

(b) Я пошел в порт, последний уж раз: завтра ученье начиналось ipf. (Б. Житков, Джарылгач) 'I went to the port, for the last time: tomorrow my study would start (lit. began).' 
In the examples, the imperfective past tense is used with (telic) situations to express that, from a vantage point in the past, the realization of the situation is supposed to occur. It can be argued that this use of the imperfective aspect is similar to the use of the imperfective present tense to indicate a future event (завтра я еду ${ }^{\text {ipf }}$ в Москву 'tomorrow, I go-IPF to Moscow') (see Forsyth 1970, 73 for such a suggestion and Barentsen 1985, 278-282 for a more explicit analysis).

6 In contrast to what Paducheva $(2006,3)$ seems to suggest, sentences expressing internal necessity form no exception. The use of the imperfective is possible to express a permanent internal necessity: После лениа мне нужно отдыхать ipf [. . .]. Тут у нас такой климат. (С. Боумен, Отвергнутый дар); 'After lunch I have to rest. That's because of our climate.' It must be noted, though, that the definition of the term internal necessity given by Van der Auwera and Plungian $(1998,80)$ is not entirely clear-cut, and leaves room for different interpretations.

7 One could also put it differently, and say that in the case of negated perfective imperatives like Смотри, не упади ${ }^{\mathrm{pf}}$ 'be aware not to fall' there is no situation that the subject can engage in.

8 In the case of non-animate subjects, the infinitive situation is either associated with people that have an intention (e. g. Машине здесь не пройти pf 'the car can't get through here'), or non-animate subjects to which a tendency to realize the infinitive situation is attributed (e. g. Дереву не расти $\mathrm{pf}^{\mathrm{pf}}$ 'the tree can't grow').

9 It must be kept in mind that we are not speaking about specific meanings associated with a form, but with different interpretations of a meaning that is underspecified with regard to the specific modality type. Because of this, some uses cannot clearly be classified as belonging to one or another modality type. To give just one example, some imperfective cases of the DI with non-controllable situations express a modality that is both close in meaning to ontic-epistemic necessity and impossibility. Consider for example the use of the idiomatic phrase нам не привыкать ('we won't get used'): Нам не привыкать ipf жить при подобном сиенарии. (Известия, 2002.10.29) 'We won't get used/won't succeed in getting used to living in such a situation'.

10 Only in the case of imperfective verbs indicating situations that have no natural end point a possibility reading is possible with an imperfective aspect: Конеино, Смирнову как каменщику с дядей Пашей не тягаться ${ }^{\mathrm{ipf}}$ (В. Белов, Воспитание по доктору Споку) 'Of course, as a mason one cannot compare Smirnov with uncle Paša'.

11 A possible reason for the speaker to use the construction with нельзя here is that the near synonym with невозможно ('impossible') can only be used with a perfective auxiliary in this context: стало ${ }^{\mathrm{pf}}$ невозможно, 'became impossible'.

12 www.rol.ru/news/med/news/04/07/12_004.htm

13 Similar contexts can be found in the case of necessity.

14 However, in specific contexts an interpretation of permission occurs, for example in contrastive contexts as the following: Девочки-икольнииы радостно шебеиут о Гарри Поттере. Чему радоваться?! Ему летать ${ }^{\mathrm{ipf}}$ на метле, а вам, девионки, в наших условиях, с ней работать $\mathrm{ipf}$ (Теледебаты, Молния, 2002.04.08) 'Our school girls are happily twittering about Harry Potter. Why be so happy? He may (gets to) fly on a broom, and you, girls, in our condition, have to work with it.' Such cases occur in the imperfective aspect, and, as such, differ from modal forms expressing permission, which prototypically occur in the perfective aspect. See Fortuin 2005, 55-58, for a more thorough analysis of the interpretation of permission.

15 www.svoboda.org/programs/OTB/2003/OBT.011303.asp

16 Paducheva (2006) gives another explanation. She sees a relation between the perfective aspect of negated imperatives, and sentences with an epistemic reading in terms of the notion of controllability. 17 The feature of expectation is also present because the starting point for the direction is that the occurrence of the non-desired situation is likely to occur. 
In the case of questions of the type (39), the speaker has an intention to perform the infinitive action but cannot realize the action, in other words, he is blocked from realizing the intended action. By asking the question the speaker asks the hearer how the blocking can be unblocked, or put differently, how he can realize the action. As such, questions like these can be seen as cases of deblocking. In some contexts neutralization between necessity and possibility can be perceived (see Fortuin 2000; Maurice 1996).

19 There are also constructions where possibility is correlated with the imperfective aspect, for example the use of the present or past tense with verbs like говорить to indicate permanent possibility: Он оиень хорошо говорит ${ }^{\text {ipf }}$ по-русски 'Hе speaks Russian very well'. Here, the use of the imperfective present tense points at an inherent and constant capacity of the subject.

www.russisk.org/modules.php?name=Forums \&file=viewtopic $\& \mathrm{p}=90766$

exler.ru/blog/item/1915/

22 www.almater.ru/job/library/7.html

23 http://www.ogoniok.com/4973/26/

24 Maurice $(1996,159)$ mentions that some sentences express the wish that a particular necessity would not exist, for example: Не вставать ${ }^{\text {ipf }}$ бы мне завтра рано! 'If only I did not have to get up early tomorrow!'. In this case, the speaker focuses on the fact that he would like not to engage in the infinitive situation and uses the imperfective aspect.

25 www.r-isp.net/library/lat/WASILXEW/hear_eng.txt

\section{REFERENCES}

Barentsen, A. A.: 1985, 'Tijd', 'Aspect' en de conjunctie POKA. Over betekenis en gebruik van enkele vormen in het moderne Russisch, Dissertatie, Universiteit van Amsterdam.

Barentsen, A. A.: 1995, 'Trexstupenčataja model' invarianta soveršennogo vida v russkom jazyke', Karolak, S. (red.), Semantika i struktura slavjanskogo vida 1, Kraków, 1-26.

Barentsen, A. A.: 1998, 'Priznak 'sekventnaja svjaz' ' i vidovoe protivopostavlenie v russkom jazyke', Čertkova, M. Ju. (red.), Tipologija vida: problemy, poiski, rě̌enija, Moskva, 43-58.

Bricyn, V.: 1990, Sintaksis i semantika infinitiva v sovremennom russkom jazyke, Kiev.

Dickey, S.: 2000, Parameters of Slavic Aspect. A Cognitive Approach, Stanford.

Forsyth, J.: 1970, A Grammar of Aspect. Usage and Meaning in the Russian Verb, Cambridge.

Fortuin, E.: 2000, Polysemy or Monosemy. Interpretation of the Imperative and the Dative-Infinitive Construction in Russian (= Dissertation series Institute for Logic, Language and Computation ILLC), Amsterdam.

Fortuin, E.: 2005, 'From possibility to necessity. The semantic spectrum of the dative-infinitive construction in Russian', Hansen, B., Karlík, P. (eds.), Modality in Slavonic Languages. New Perspectives, München, 39-60.

Fortuin, E.: 2006, 'On the use of dative subjects in the construction of anteriority in Russian', Russian Linguistics 30(3), 321-357.

Maurice, F.: 1995, 'Zur Verteilung von Möglichkeit und Notwendigkeit im russischen modalen Infinitiv', Dippong, H. (ed.), Linguistische Beiträge zur Slavistik aus Deutschland, Österreich und der Schweiz. III. JungslavistInnen-Treffen, Hamburg 1994 (= Specimina Philologiae Slavicae, Supplementband 42), München, 147-158.

Maurice, F.: 1996, Der modale Infinitiv in der modernen russischen Standardsprache (= Slavistische Beiträge 340), München.

Mets, N. A.: 1985, Praktičeskaja grammatika russkogo jazyka dlja zarubežnyx prepodavatelejrusistov, Moskva.

Paducheva, E.: 2006, Modality, Negation, and Aspect. The case of the Russian možet and dolžen, available online: <www.lexicograph.ru/files/modality_aspect_negation_hnd.doc> (7-31-2007).

Proeme, H.: 2003, 'Het gebruik van de infinitief', Houtzagers, P. (ed.), Russische Grammatica, Bussum, CD-ROM. 
Rappaport, G. C.: 1985, 'Aspect and modality in the contexts of negation', Flier, M., Timberlake, A. (eds.), The Scope of Slavic Aspect, Columbus, 194-223.

Rassudova, O. P.: 1968, Upotreblenie vidov glagola v russkom jazyke, Moskva.

Russkaja Grammatika, 1980, t. 1-2, red. Švedova, N. Ju., Moskva.

Talmy, L.: 1985, 'Force dynamics in language and thought', Papers from the Parasession on Causatives and Agentivity at the Twenty-First Regional Meeting of the Chicago Linguistic Society, Chicago, 293-337.

Timofeev, K. A.: 1950, 'Ob osnovnyx tipax infinitivnyx predloženij $\mathrm{v}$ sovremennom russkom literaturnom jazyke', Vinogradov, V. V. (red.), Voprosy sintaksisa sovremennogo russkogo jazyka, Moskva, 257-301.

Trnavac, R.: 2006, Aspect and Subjectivity in Modal Constructions (= LOT Dissertation Series 143), Leiden.

Van der Auwera, J., Plungian, V. A.: 1998, 'Modality's semantic map', Linguistic Typology 2, 79124.

Wiemer, B.: 2001, 'Aspect choice in non-declarative and modalized utterances as extensions from assertive domains. Lexical semantics, scopes, and categorical distinctions in Russian and Polish', Bartels, H. et al. (eds.), Untersuchungen zur Morphologie und Syntax im Slavischen (= Studia Slavica Oldenburgensia 6), 195-221.

Wierzbicka, A.: 1987, 'The semantics of modality', Folia Linguistica, Acta Societatis Linguisticae Europaeae, Tomus XXI(1), 25-43.

Universiteit Leiden

EGBERT FORTUIN

Leiden, Netherlands

E.Fortuin@let.leidenuniv.nl 